Artikel

\title{
PENGARUH PENERAPAN MODEL KONSIDERASI TERHADAP PEMBENTUKAN SIKAP SISWA DALAM PEMBELAJARAN SOSIOLOGI DI KELAS XI IPS SMA ADABIAH PADANG
}

\author{
Oleh: Junaidi dan Mutia Kahanna
}

\begin{abstract}
ABSTRAK
Dalam pembelajaran sosiologi di kelas XI IPS SMA Adabiah Padang beberapa siswa belum mampu menunjukkan beberapa sikap sikap toleransi dan nondiskriminasi terhadap masyarakat lain yang memiliki etnis dan agama yang berbeda. Untuk mengatasi masalah itu peneliti memilih model pembelajaran konsiderasi. Tujuan dari penelitian ini untuk mengetahui pengaruh penerapan model konsiderasi terhadap pembentukan sikap siswa dalam pembelajaran sosiologi di kelas XI IPS SMA Adabiah Padang.

Jenis penelitian ini adalah kuantitatif dengan tipe penelitian eksperimen dengan desain Pretest Posttest Control Group Design. Populasi penelitian ini adalah seluruh siswa kelas XI IPS SMA Adabiah Padang. Sampel yang terpilih sebagai kelas eksperimen adalah siswa kelas XI IPS 2 dan sebagai kelas kontrol adalah XI IPS 5. Instrumen penelitian adalah berupa angket untuk memperoleh data mengenai sikap siswa terhadap mata pelajaran sosiologi dengan menggunakan model konsiderasi, selanjutnya hasil data yang diperoleh dianalisis dengan menggunakan uji t.

Berdasarkan deskripsi dan analisis data yang telah dilakukan, dapat disimpulkan bahwa rata-rata skor sikap siswa dalam pembelajaran sosiologi kelas eksperimen adalah 50,74, sedangkan rata-rata skor sikap siswa dalam pembelajaran sosiologi kelas kontrol adalah 43,85 , pengolahan data tes dilakukan dengan menggunakan uji t. Setelah dianalisis diperoleh $\mathrm{t}$ hitung $=2,88$ dengan taraf nyata $\alpha=0,05$ dan $\mathrm{df}=77$, sedangkan $\mathrm{t}$ tabel $=2,00$ karena $\mathrm{t}$ hitung $>\mathrm{t}$ tabel maka hipotesis nol $\left(\mathrm{H}_{0}\right)$ ditolak. Oleh karena itu, berdasarkan data di atas dapat disimpulkan bahwa pembelajaran dengan model konsiderasi berpengaruh terhadap sikap siswa dalam pembelajaran sosiologi di kelas XI IPS SMA Adabiah Padang.
\end{abstract}

Kata-kata kunci: pembelajaran sosiolgi, konsiderasi, sikap.

\section{A. Pendahuluan}

Pendidikan di Indonesia bertujuan membentuk warga negara yang beriman dan bertaqwa terhadap Tuhan Yang Maha Esa, berakhlak mulia, sehat, berilmu, 
cakap, kreatif, mandiri dan menjadi warga negara yang demokratis serta bertanggung jawab. Tujuan tersebut menekankan pada pengetahuan, keterampilan dan sikap.

Pembentukan sikap diupayakan salah satunya melalui pembelajaran sosiologi. Pembelajaran sosiologi diharapkan mampu membentuk sikap anak ke arah yang lebih baik. Oleh karena itu, guru sosiologi harus mampu menyeimbangkan pembelajaran sosiologi pada ranah kognitif dan afektif terutama dalam pembentukan sikap siswa. Guru sosiologi harus mampu menyajikan materi yang relevan dengan konteks sosial peserta didik.

Upaya untuk mewujudkan tujuan pembelajaran sosiologi tersebut, hingga kini masih sangat membutuhkan usaha yang kuat dan serius dari pihak sekolah, terutama guru. Salah satu materi sosiologi yang sarat dengan pembentukan sikap anak dalam masyarakat adalah materi masyarakat multikultural. Menurut Kartanegara (2004:8) ada 4 sikap tuntutan yang harus timbul dari mempelajari masyarakat multikultural, yaitu toleransi, empati, humanis dan non diskriminasi.

Berdasarkan hasil pengamatan pada pembelajaran materi Masyarakat Multikultural Tahun Ajaran 2009/2010, beberapa siswa belum mampu menunjukkan beberapa sikap toleransi dan nondiskriminasi. Mereka intoleransi dan nondiskriminasi terhadap masyarakat lain yang memiliki etnis dan agama yang berbeda, yang mana hal ini dapat dilihat ketika mereka mengeluarkan pendapat mengenai konflik yang terjadi di Poso.

Salah satu penyebab terjadinya hal tersebut diduga karena tidak sesuainya metode pembelajaran yang dilakukan oleh guru untuk membentuk sikap siswa 
dalam pembelajaran sosiologi terutama dalam materi masyarakat multikultural. Guru menggunakan metode ceramah yang hanya memberikan informasi kepada siswa, sehingga kurang dapat membentuk sikap siswa dalam pembelajaran sosiologi terutama dalam materi masyarakat multikultural.

Adapun alternatif yang diduga dapat digunakan untuk pembentukan sikap siswa adalah strategi pembelajaran afektif model konsiderasi. Strategi pembelajaran afektif pada umumnya menghadapkan siswa pada situasi yang mengandung konflik atau situasi yang problematis, dan membawa siswa seandainya berada dalam situasi terrsebut. Melalui situasi ini diharapkan peserta didik dapat mengambil keputusan berdasarkan nilai yang dianggapnya baik.

Model konsiderasi menekankan kepada strategi pembelajaran yang dapat membentuk sikap. Tujuan model konsiderasi ini adalah agar peserta didik memiliki kepedulian terhadap orang lain dalam hal bergaul secara harmonis, saling memberi dan menerima. Sanjaya (2006:277-278) menyatakan bahwa pembelajaran sikap pada dasarnya adalah membantu anak agar dapat mengembangkan kemampuan untuk bisa hidup bersama secara harmonis, peduli, dan merasakan apa yang dirasakan orang lain.

Berdasarkan uraian di atas, maka timbul pertanyaan apakah terdapat pengaruh penerapan model konsiderasi terhadap pembentukan sikap siswa dalam pembelajaran sosiologi di kelas XI IPS SMA Adabiah Padang? Penelitian ini bertujuan untuk mengetahui pengaruh penerapan model konsiderasi terhadap pembentukan sikap siswa dalam pembelajaran sosiologi di kelas XI IPS SMA Adabiah Padang. 


\section{B. Metodologi Penelitian}

Jenis penelitian ini adalah kuantitatif dengan tipe penelitian eksperimen. Desain penelitian ini menggunakan rancangan Pretest-Posttest Control Group Design, yaitu sebuah rancangan eksperimen (true experimental design) karena kedua kelas dipilih sesuai dengan kriteria yang dipersyaratkan penelitian. Populasi dalam penelitian ini adalah semua siswa kelas XI IPS SMA Adabiah Padang yang terdaftar pada tahun ajaran 2010-2011 yang berjumlah 289 orang. Sampel dipilih dengan memakai cluster random sampling. Kelas yang terpilih sebagai kelas eksperimen yaitu kelas XI IPS 2 dan kelas XI IPS 5 sebagai kelas kontrol.

Variabel pada penelitian ini terdiri variabel bebas yaitu model pembelajaran konsiderasi, variabel terikat yaitu pembentukan sikap, dan variabel IQ, guru, dan materi pembelajaran. Instrumen yang digunakan dalam penelitian ini adalah angket. Angket digunakan untuk memperoleh data mengenai sikap siswa siswa tehadap mata pelajaran sosiologi dengan menggunakan model konsiderasi dengan membagi hal-hal yang spesifik tentang apa yang ingin diukur dan dari mana sumbernya.

Angket dalam penelitian ini menggunakan item pertanyaan secara terbuka. angket diuji cobakan pada kelas yang memiliki level yang sama dengan kelas sampel. Dari hasil uji coba dilakukan analisis angket untuk mengetahui validitas dan reliabilitas. Seterusnya setelah data terkumpul dilakukan uji normalitas dan uji hipotesis. 


\section{Hasil Penelitian dan Pembahasan}

\section{Deskripsi Data}

Berdasarkan data yang diperoleh dari hasil analisis pretest diperoleh skor rata-rata kelas eksperimen: 22,92 dan kelas kontrol: 23,93 sebagaimana dapat dilihat pada tabel berikut.

Tabel 10:

Hasil Pretest Nilai Rata-rata, Standar Deviasi dan Varian Data Kelas Eksperimen dan Kelas Kontrol

\begin{tabular}{|c|c|c|c|c|}
\hline Kelas & $\mathbf{N}$ & Rata-rata & $\mathbf{S}$ & $\mathbf{S}^{\mathbf{2}}$ \\
\hline Eksperimen & 39 & 22,92 & 5,20 & 27,01 \\
\hline Kontrol & 40 & 23,93 & 5,15 & 26,53 \\
\hline
\end{tabular}

Berdasarkan tabel di atas dapat dilihat perbedaan rata-rata kelas eksperimen dengan kelas kontrol tidak jauh berbeda. Setelah dilakukan uji pretest tidak terdapat perbedaan antara kelas eksperimen dan kelas kontrol dimana $t_{\text {hitung }}$ $=-0,86$ dengan taraf nyata $=0,05 \mathrm{dan} \mathrm{df}=77$ diperoleh $\mathrm{t}_{\text {tabel }}=2,00$ berarti $\left(\mathrm{t}_{\text {hitung }}<\right.$ tabel)

Data yang diolah adalah data dari soal posttest. Hasil penggunaan model konsiderasi pada materi pelajaran masyarakat multikultural diperoleh melalui tes akhir berupa angket yang telah diuji coba, dianalisis dan disempurnakan dalam angket terbuka yang pernyataannya mencakup aspek kognisi, afeksi, dan konasi dengan jumlah item angket sebanyak 30 butir. Hal ini dilakukan untuk melihat validitas angket dan realibilitas angket yang akan diuji di tempat penelitian dilakukan. Dari 30 item angket uji coba didapat 24 item angket untuk pretest dan posttest. 
Selanjutnya data sikap siswa di atas, dihitung dengan menggunakan rumus statistik pada kedua kelas sampel tersebut sehingga didapat nilai rata-rata, standar deviasi, dan varians kelas eksperimen dan kelas kontrol. Hasil perhitungan memperlihatkan bahwa terdapat satu perbedaan hasil belajar posttest kelas eksperimen dan kelas kontrol, di mana posttest kelas eksperimen memiliki nilai rata-rata lebih tinggi dari kelas kontrol, yaitu kelas eksperimen sebesar $=50,74$ dan kelas kontrol sebesar $=43,85$. Hasil ini juga sesuai dengan varians yang dimilikinya dalam kelompok analisis data lapangan ternyata skor sikap siswa kelas eksperimen lebih homogen dari kelas kontrol.

Tabel 11 :

Hasil Posttest Nilai Rata-Rata, Standar Deviasi Dan Varian Data

\begin{tabular}{|l|c|c|c|c|}
\hline \multicolumn{1}{|c|}{ Kelas } & N & Rata-rata & S & $\mathbf{S}^{\mathbf{2}}$ \\
\hline Eksperimen & 39 & 50,74 & 10,41 & 108,45 \\
\hline Kontrol & 40 & 43,85 & 10,79 & 116,59 \\
\hline
\end{tabular}

Setelah dilakukan analisis deskriptif secara umum, maka akan dilakuakan analisis deskriptif secara terpisah dari tiap-tiap komponen sikap, yang terdiri dari kognisi, afeksi, dan konasi. Setelah dilakukan perhitungan rata-rata diketahui bahwa skor kognisi kelas eksperimen lebih baik dari kelas kontrol, akan tetapi nilai variannya lebih baik di kelas kontrol karena sebaran datanya lebih baik.

Tabel 12:

Hasil Posttest Nilai Rata-Rata, Standar Deviasi Dan Varian Data Kognisi

\begin{tabular}{|l|c|c|c|c|}
\hline \multicolumn{1}{|c|}{ Kelas } & N & Rata-rata & S & $\mathbf{S}^{\mathbf{2}}$ \\
\hline Eksperimen & 39 & 19,44 & 4,01 & 16,09 \\
\hline Kontrol & 40 & 16,50 & 3,67 & 13,49 \\
\hline
\end{tabular}


Pada angket afeksi terdiri dari 8 item pernyatan yang menanyakan persetujuan siswa terhadap suatu objek. Setelah dilakukan perhitungan rata-rata, standar deviasi dan varian terlihat rata-rata kelas eksperimen lebih baik dari kelas kontrol.

Tabel 13 :

Hasil Posttest Nilai Rata-Rata, Standar Deviasi Dan Varian Data Afeksi

\begin{tabular}{|l|c|c|c|c|}
\hline \multicolumn{1}{|c|}{ Kelas } & N & Rata-rata & S & $\mathbf{S}^{2}$ \\
\hline Eksperimen & 39 & 15,36 & 3,49 & 12,23 \\
\hline Kontrol & 40 & 12,85 & 4,75 & 22,59 \\
\hline
\end{tabular}

Pada angket konasi terdiri dari 8 item pernyatan yang menanyakan kecendrungan siswa bertindak. Setelah dilakukan perhitungan rata-rata, standar deviasi dan varian terlihat rata-rata kelas eksperimen lebih baik dari kelas kontrol, akan tetapi nilai variannya lebih baik di kelas kontrol karena sebaran datanya lebih baik.

Tabel 14 :

Hasil Posttest Nilai Rata-Rata, Standar Deviasi Dan Varian Data Angket Konasi

\begin{tabular}{|l|c|c|c|c|}
\hline \multicolumn{1}{|c|}{ Kelas } & N & Rata-rata & S & $\mathbf{S}^{\mathbf{2}}$ \\
\hline Eksperimen & 39 & 15,10 & 4,02 & 16,15 \\
\hline Kontrol & 40 & 13,37 & 3,48 & 12,10 \\
\hline
\end{tabular}

\section{Uji Hipotesis (Uji t)}

Pada analisis pretest kelas kontrol dan kelas eksperimen diketahui bahwa tidak ada perbedaan antara kelas eksperimen dan kelas kontrol. Hal ini diketahui 
dari uji $\mathrm{t}$, pada perhitungan uji $\mathrm{t}$ pretest diperoleh $\mathrm{t}_{\text {hitung }}=0,86$ dengan $\mathrm{t}_{\text {tabel }}=2,00$

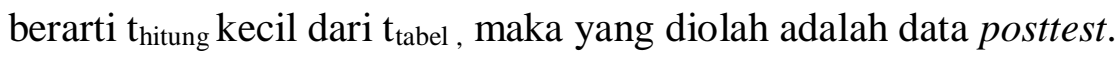

Setelah diketahui kelas sampel berdistribusi normal dan memiliki variansi yang homogen, maka dilakukan uji hipotesis secara statistik, yaitu dengan menggunakan uji t terhadap nilai skor posttest yang diperoleh. Uji t bertujuan untuk mengetahui apakah pembentukan sikap kelas eksperimen lebih baik dari kelas kontrol.

Pada perhitungan uji hipotesis posttest, didapat nilai $t_{\text {tabel }}$ sebesar $=2,00$ dan $t_{\text {hitung }}$ sebesar $=2,88$. Dengan demikian, $t_{\text {tabel }}<t_{\text {hitung }}$ maka hipotesis nol $\left(\mathrm{H}_{0}\right)$ ditolak. Hal ini berarti, proses pembelajaran dengan menggunakan model konsiderasi mempunyai pengaruh terhadap pembentukan sikap siswa dalam pembelajaran sosiologi pada kelas XI IPS SMA Adabiah Padang.

\section{A. Pembahasan}

Dari hasil penelitian ini dapat dilihat bahwa pembelajaran dengan mengunakan model konsiderasi pada materi pelajaran Masyarakat Multikultural dalam pembelajaran sosiologi dapat mempengaruhi pembentukan sikap siswa. Berdasarkan data penelitian yang penulis lakukan terlihat bahwa rata-rata kelas eksperimen adalah 50,74 sedangkan rata-rata kelas kontrol adalah 43,85. Hasil ini menunjukkan bahwa nilai yang diperoleh siswa yang diberi perlakuan dengan menggunakan model konsiderasi lebih tinggi dari rata-rata nilai kelas kontrol. Selain itu, berdasarkan uji $\mathrm{t}$ yang dilakukan didapat $\mathrm{t}_{\text {hitung }}=2,88$ dengan taraf nyata 0,05 dan df 77 diperoleh $t_{\text {tabel }}$ sebesar $=2,00$ karena $t_{\text {tabel }}<t_{\text {hitung. }}$. Dengan 
demikian maka hipotesis penelitian ini diterima. Begitu juga pada angket kognisi didapat nilai $t_{\text {tabel }}=2,00$ dan $t_{\text {hitung }}=3,38$, jadi $t_{\text {hitung }}>t_{\text {tabel }}$. Angket afeksi didapat nilai nilai $t_{\text {tabel }}=2,00$ dan $t_{\text {hitung }}=2,67$, jadi $t_{\text {hitung }}>t_{\text {tabel. }}$. Angket konasi didapat nilai nilai $\mathrm{t}_{\text {tabel }}=2,00$ dan $\mathrm{t}_{\text {hitung }}=2,06$, jadi $\mathrm{t}_{\text {hitung }}>\mathrm{t}_{\text {tabel }}$.

Berdasarkan deskripsi data yang dilakukan secara terpisah guna untuk melihat apakah tiap-tiap komponen dari sikap untuk kelompok angket aspek kognisi, afeksi, dan konasi berbeda antara kelas eksperimen dibanding kelas kontrol. Hal ini dapat dibuktikan bahwa rata-rata kelas eksperimen untuk angket kognisi $=19,44$ dengan standar deviasi $=4,01$ dan kelas kontrol rata-ratanya $=16,50$ dengan standar deviasi $=3,67$. Hasil $t_{\text {hitung }}=3,38$ (dengan taraf nyata 0,05), dengan demikian model konsiderasi untuk angket kognisi lebih baik hasilnya dari kelas kontrol.

Pada angket afeksi juga terlihat perbedaan nilai rata-rata antara kelas kontrol dengan kelas eksperimen. Hal ini dapat dilihat dari nilai rata-rata kelas eksperimen $=15,36$ dengan standar deviasi $=3,49$ dan kelas kontrol rata-ratanya $=$ 12,85 dengan standar deviasi $=4,75$. Hasil $t_{\text {hitung }}=2,67$ (dengan taraf nyata 0,05$)$, pada angket afeksi ini nilai rata-rata kelas eksperimen lebih tinggi dari pada kelas kontrol.

Perbedaan antara kelas eksperimen dan kelas kontrol juga terlihat pada angket konasi. Setelah dilakukan perhitungan rata-rata kelas eksperimen untuk angket konasi $=15,10$ dengan standar deviasi $=$ 4,02 dan untuk kelas kontrol rataratanya $=13,37$ dengan standar deviasi $=3,48$. Hasil $t_{\text {hitung }}=2,06$ (dengan taraf 
nyata 0,05$)$, disini juga terlihat kalau hasil yang diperoleh oleh kelas eksperimen lebih baik hasilnya dari kelas kontrol.

Untuk melihat pencapaian sikap siswa dalam pembelajaran sosiologi, dapat di lihat dengan menggunakan uji t yang dilakukan pada tiap komponen indikator sikap.

Tabel 15

\section{Hasil Uji t Tiap Komponen Indikator Angket}

\begin{tabular}{|c|c|c|c|c|c|}
\hline No & Indikator & $\mathbf{t}_{\text {hitung }}$ & $\mathbf{t}_{\text {tabel }}$ & Syarat & Keterangan \\
\hline 1. & Kognisi & 3,38 & 1,994 & $\mathrm{t}_{\text {hit }}>\mathrm{t}_{\mathrm{tab}}$ & $\mathrm{H}_{\mathrm{i}}$ diterima \\
\hline 2. & Afeksi & 2,67 & 1,994 & $\mathrm{t}_{\text {hit }}>\mathrm{t}_{\mathrm{tab}}$ & $\mathrm{H}_{\mathrm{i}}$ diterima \\
\hline 3. & Konasi & 2,06 & 1,994 & $\mathrm{t}_{\text {hit }}>\mathrm{t}_{\mathrm{tab}}$ & $\mathrm{H}_{\mathrm{i}}$ diterima \\
\hline
\end{tabular}

Berdasarkan data di atas, hipotesis penelitian ini diterima yang menunjukan bahwa terdapat pengaruh yang signifikan terhadap sikap siswa dalam pembelajaran sosiologi dengan menggunakan model konsiderasi pada pokok bahasan masyarakat multikultural. Ini disebabkan pada kelas eksperimen siswa dihadapkan pada suatu kasus yang terjadi dalam kehidupan sehari-hari dan guru meminta siswa untuk menganalisis situasi masalah dan menulis tanggapannya. Selain itu, setiap siswa juga bertukar pendapat dan bekerja sama untuk memecahkan masalah yang sedang didiskusikan. Adapun pada saat guru memberikan pertanyaan, siswa termotivasi untuk menemukan jawabannya.

Melalui pembelajaran model konsiderasi, guru mampu merangsang siswa untuk berpikir kritis dan rasional dalam memecahkan masalah yang ada serta mengarahkan siswa untuk menganalisis, merespon tanggapan orang lain, dan mendengarkan perspektif yang berbeda diantara mereka. Langkah-langkah dari penerapan model konsiderasi ini sesuai dengan indikator pada komponen sikap , 
yaitu kognisi, afeksi dan konasi. Model konsiderasi ini baik untuk kognisi siswa karena adanya saling tukar pendapat dan argumen di antara mereka sehingga pada akhirnya akan membantu keyakinan siswa terhadap suatu hal yang benar. Selanjutnya model konsiderasi ini baik untuk afeksi siswa karena guru menghadapkan siswa pada suatu kasus yang dekat dengan siswa, yaitu yang benar-benar yang terjadi dalam masyarakat, sehingga hal ini akan baik untuk perasaan siswa terhadap suatu objek. Selanjutnya model konsiderasi ini baik untuk konasi siswa karena dalam memberikan suatu kasus guru menciptakan situasi yang membawa seandainya siswa berada dalam situasi tersebut, sehingga pada akhirnya siswa mampu menetapkan sendiri tindakan apa yang harus dilakukannya.

Model pembelajaran konsiderasi ini menghadapkan siswa pada situasi yang mengandung konflik atau problematis, jadi masing-masing siswa diharuskan untuk menganalis permasalahan yang ada dan menulis tanggapannya. Selama mengikuti proses pembelajaran semua siswa terlihat aktif untuk mengemukakan pendapat dan merespon tanggapan dari temannya yang lain karena tiap jawaban dan tanggapan yang diberikan, guru memberikan poin sehingga siswa berebut untuk menjawab.

Pembelajaran dengan model konsiderasi pada materi pelajaran yang diterapkan kepada siswa juga dilengkapi dengan bahan ajar pada materi Masyarakat Multikultural. Sebelumnya bahan ajar tersebut dibaca dan dipahami oleh siswa dirumah, dan guru juga mengharuskan semua siswa untuk membuat laporan bacaannya. Hal ini dapat membantu siswa dalam memahami materi 
sehingga akan lebih mudah dalam menganalisis permasalahan yang diberikan setiap pertemuannya.

Pada kelas kontrol, kegiatan belajar mengajar dilaksanakan seperti biasa dengan metode ceramah. Siswa diminta untuk mendengarkan penjelasan yang diberikan guru yang berkaitan dengan pelajaran yang dipelajari pada pertemuan tersebut yaitu materi masyarakat multikultural. Selanjutnya guru meminta masing-masing siswa untuk menulis satu pertanyaan mengenai materi yang telah diberikan, lalu guru mengumpulkan pertanyaan dari masing-masing siswa dan membagikannya secara acak kepada siswa yang lain. Selanjutnya guru meminta siswa untuk menulis jawaban dari pertanyaan temannya sendiri. Pada awalnya guru memberikan kesempatan kepada siswa yang mau untuk membacakan dan menjawab pertanyaan dari temannya, tetapi tidak ada satu orang siswa pun yang mau. Oleh karena itu, guru mengambil nama siswa secara acak melalui buku absen dan meminta siswa tersebut membacakan pertanyaan dan jawabannya. Siswa kebanyakan hanya mencatat materi pembelajaran yang disampaikan guru dan menerima apa yang diberikan guru, siswa kurang memiliki inisiatif untuk bertanya apabila ada materi yang tidak dipahami.

\section{Implikasi}

Pembelajaran model konsiderasi memberikan dampak yang baik terhadap pembentukan sikap siswa, yang terbukti melalui rata-rata nilai posttest kelas eksperimen lebih tinggi dari pada kelas kontrol. Dengan demikian ini berarti, model pembelajaran konsiderasi bisa diterapkan untuk meningkatkan sikap siswa, karena model konsiderasi mampu merangsang siswa untuk berpikir kritis dan 
rasional dalam memecahkan masalah yang ada serta mengarahkan siswa untuk menganalisis, merespon tanggapan orang lain, lalu mendengarkan perspektif yang berbeda diantara mereka, dan merumuskan sendiri tindakan yang harus dilakukannya. Dengan demikian siswa mampu mencapai tujuan pembelajaran model konsiderasi yang sesuai dengan tujuan pembelajaran sosiologi yang dimaksudkan untuk mengembangkan sikap siswa yang rasional dan kritis dalam menghadapi kemajemukan masyarakat, kebudayaan, situasi sosial serta berbagai masalah sosial yang ditemukan dalam kehidupan sehari-hari.

Agar model pembelajaran konsiderasi ini dapat diterapkan secara maksimal oleh guru, maka guru harus mencari kasus-kasus menarik yang terjadi dalam masyarakat yang benar-benar mampu untuk merangsang sikap siswa yang kritis dan rasional siswa terhadap berbagai macam masalah sosial. Selain itu guru sebaiknya juga menggunakan media pembelajaran berupa video yang berisi tayangan kasus-kasus dalam masyarakat, sehingga siswa akan lebih mudah untuk menganalisisnya karena dapat melihat secara nyata melalui tayangan video tersebut

\section{Penutup}

Berdasarkan hasil penelitian dapat disimpulkan bahwa model pembelajaran konsiderasi dapat memberikan pengaruh positif terhadap pembentukan sikap siswa dalam pembelajaran sosiologi pada kelas XI IPS SMA Adabiah Padang. Hal ini terlihat dengan tingginya nilai rata-rata siswa kelas eksperimen dari pada nilai rata-rata siswa kelas kontrol. Begitu juga dengan aspek 
kognisi, afeksi, dan konasi skornya lebih tinggi hasilnya kelas ekperimen dibandingkan kelas kontrol.

Model konsiderasi ini baik untuk kognisi siswa karena adanya saling tukar pendapat dan argumen di antara mereka sehingga pada akhirnya akan membantu keyakinan siswa terhadap suatu hal yang benar. Selanjutnya model konsiderasi ini baik untuk afeksi siswa karena guru menghadapkan siswa pada suatu kasus yang dekat dengan siswa, yaitu yang benar-benar yang terjadi dalam masyarakat, sehingga hal ini akan baik untuk perasaan siswa terhadap suatu objek. Selanjutnya model konsiderasi ini baik untuk konasi siswa karena dalam memberikan suatu kasus guru menciptakan situasi yang membawa seandainya siswa berada dalam situasi tersebut, sehingga pada akhirnya siswa mampu menetapkan sendiri tindakan apa yang harus dilakukannya.

Dari hasil penelitian yang diperoleh, maka penulis mengemukakan beberapa saran yang diharapkan dapat memberi manfaat untuk meningkatkan sikap siswa dalam pembelajaran sosiologi, yakni:

Berdasarkan kesimpulan di atas disarankan agar guru menerapkan model pembelajaran konsiderasi secara maksimal sehingga mampu merangsang sikap siswa yang kritis dan rasional siswa terhadap berbagai macam masalah sosial. 


\section{DAFTAR PUSTAKA}

Arikunto, Suharsimi. 2002. Prosedur Penelitian (Suatu Pendekatan Praktek). Jakarta: Rineka Cipta 2007. Dasar-Dasar Evaluasi Pendidikan. Jakarta: Rineka Cipta

Creswell, John.W. 2002. Desain Penelitian Pendekatan Kualitatif dan Kuantitatif. Alih Bahasa: Angkatan III dan IV KIK-UI dan Nu Khabibah. Jakarta: Tirtayasa raya

Darmadi, Hamid. 2003. Dasar Konsep Pendidikan Moral. Bandung: CV. Alfabeta

Depdiknas. 2003. Standar Kompetensi Mata Pelajaran Sosiologi untuk SMA dan MA Kurikulum 2004. Jakarta: Balitbang Depdiknas.

Kartanegara, Mulyadhi. 2004. Tuntutan Sikap Terhadap Masyarakat Multikultural. Yogyakarta: Suara Muhammadiyah Edisi 04 Volume 89

Punaji, Setyosari. 2010. Metode Penelitian Pendidikan dan Pengembangan. Jakarta: Predana Media Group.

Sanjaya, Wina. 2006. Strategi Pembelajaran Berorientasi Standar Proses Pendidikan. Jakarta: Kencana.

Sobur, Alex. 2003. Psikologi Umum. Bandung: CV. Pustaka Setia.

Sudjana, Nana. 2005. Metoda Statika. Bandung: PT. Tarsito Bandung

Sugiyono. 2008. Statistika Untuk Penelitian. Bandung : CV. Alfabeta.

Sukardi. 2003. Metodelogi Penelitian Pendidikan. Jakarta : Bumi Aksara.

Wawan, A. 2010. Teori \& Pengkuran : Pengetahuan, Sikap, dan Perilaku Manusia. Yogyakarta: Nuha Medika.

Zafri. 2000. Metode Penelitian Pendidikan. Padang: Universitas Negeri Padang. 